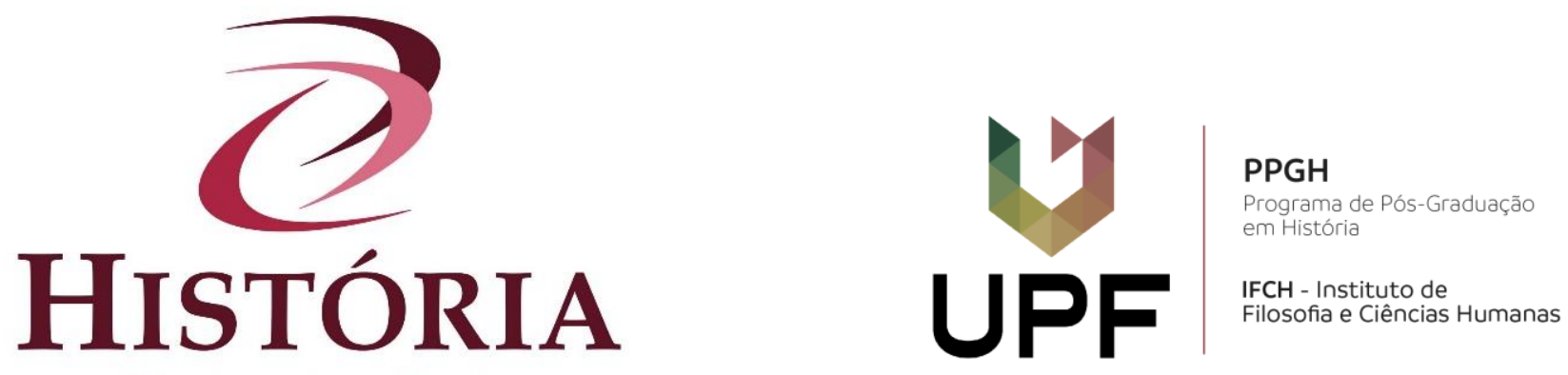

debates e tendências

\title{
Os indígenas na enxada: processos produtivos e de controle social na Colônia Militar de Caseros - 1858-1878
}

\author{
Indigenous in the hoe: productive processes and social control in the Military Colony \\ of Caseros - 1858-1878
}

Los nativos en la azada: procesos de producción y control social en la Colonia Militar de Caseros-1858-1878

João Carlos Tedesco ${ }^{\mathrm{i}}$

\begin{abstract}
Resumo: O artigo analisa a presença e a importância dos indígenas na Colônia Militar de Caseros, entre 1858-1878. A referida colônia foi instituída no norte da Província do Rio Grande do Sul com a intenção de controlar o território para viabilizar a economia pastoril, a apropriação privada e econômica da terra, o extrativismo da erva mate, abrir estradas que ligassem com a região das missões e o centro do país, bem como garantir passagem dos tropeiros e viabilizar a produção agrícola. Para isso, havia necessidade de controlar, aldear e envolver os indígenas no empreendimento. Nesse sentido, a produção agrícola, a abertura de estradas e a extração de erva mate teriam a presença dos indígenas. Porém, houve resistências e muitos conflitos nessa tentativa. O texto nos auxilia na compreensão histórica das atuais demandas indígenas pela terra na região norte do estado.
\end{abstract}

Palavras-chave: Colônia Militar. Indígenas. Agricultura. Aldeamentos.

Abstract: The article analyzes the presence and the importance of the natives in the Military Colony of Caseros between 1858-1878. The said colony was instituted in the north of the Province of Rio Grande do Sul with the intention of controlling the territory to make the pastoral economy viable, a private and economic appropriation of the land, the extractivism of the mate tea, roads to connect the missions region and the center of the country, the passage of mule troops and to enable an agricultural production. For this, there was a need to control, village and involve the indigenous in the enterprise. In this sense, agriculture, the opening of roads and the extraction of mate tea would have the presence of indigenous peoples. However, there were resistance and many conflicts in this attempt. The text in the current historical understanding in indigenous demands for land in the northern region of the State.

Keywords: Military Colony. Indigenous peoples. Agriculture. Villages.

Resumen: El artículo analiza la presencia y la importancia de la Colonia Militar indígena de Caseros, entre 1858-1878. Esta colonia se estableció en el norte de la Provincia de Rio Grande do Sul con la intención de controlar el territorio para permitir que el cultivo, privado y económico de la propiedad de la tierra, la extracción de la yerba mate, abrir caminos a la región de las misiones y del centro del país, así como garantizar el paso de arrieros y la producción agrícola. Para esto, no había necesidad de control, aldear e involucrar a los pueblos indígenas en la empresa. En este sentido, la producción agrícola, la apertura de 
caminos y extracción de la yerba mate tendría la presencia de los indígenas. Sin embargo, hubo resistencia y muchos conflictos en el intento. El texto ayuda en la comprensión histórica actual en las demandas indígenas por la tierra en la región norte del estado.

Palabras-clave: Colonia militar. Indígenas. Agricultura. Aldeamentos.

\section{Introdução}

Foram várias as formas utilizadas, tanto pela Coroa Portuguesa, quanto pelo Governo Imperial e republicano (esse último, apenas nas primeiras décadas), para defender e povoar o território nacional. A primeira metade do século XIX foi muito intensa nesse sentido. As colônias militares demonstraram ser as que poderiam resolver as questões territoriais em evidencia no período. Nesse amplo período histórico, sempre houve conflitos na definição de limites das fronteiras. Invasões, contrabandos, litígios, povoamento e problemas com a ocupação do interior, em razão da presença e resistência indígena e das amplas dificuldades de comunicação e interligação regional, eram, no período, lugar comum.

Juntamente com essas questões de ordem geográfico-territorial, havia uma série de medidas administrativas em sinergias com a questão da colonização, na intenção de atrair pessoas para o interior do país, através de frentes de expansão territorial, ocupacional e produtiva, bem como controlar e coibir os ataques de indígenas (BARROS, 1980; BRÜGGEMANN, 2013).

Em meados do século XIX havia uma efervescente discussão em torno das questões ligadas à terra, independências de províncias, aldeamentos indígenas, reocupação espacial e as em torno do controle público do território. Os indígenas estavam no centro das discussões. Para viabilizar o povoamento, a normatização e a venda das terras, havia que se tomar medidas contra a resistência indígena, a qual era expressiva da usurpação de territórios, de contraposição aos aldeamentos, processos de integração e assimilação, dentre outras questões. Um Ministro do Império em 1859, revela essa preocupação e enfatiza a necessidade de se criarem colônias com características militares para solucionar esse problema:

Com o fim de proteger a população de certas localidades do interior contra correrias dos índios selvagens e facilitar as comunicações e o comércio, tem sido criadas estas colônias, mas podem tais estabelecimentos prestar ainda outros serviços importantes; o de auxiliar os núcleos coloniais civis que se fundarem em suas colônias. ${ }^{\text {ii }}$

O espaço geográfico, com a presença de guarnições militares, transformar-se-ia em território militar controlado e movido pela esfera pública. Desse modo, confins nacionais e 
interioranos poderiam estar em correlação, tornando-se, com isso, translocais, como de pertencimento nacional, ou seja, não seriam mais espaços desconhecidos.

A escolha do local da colônia nem sempre era fácil, muitas vezes, objeto de grandes embates e dissensos, pois, em razão do desconhecimento, nem sempre coincidia com um melhor solo para a produção agrícola e para a atração de povoamento e aquisição da terra; ou, então, os primeiros se correlacionavam, mas havia o problema da comunicação e interligação de regiões, bem como o escoamento da possível produção e extrativismo. A existência de água potável também era um fator a levar em conta. Essa questão logística e sinérgica demandava a presença de pessoal técnico tais como engenheiros, agrimensores, profissionais da saúde (médicos e enfermeiros) para dinamizar as atividades hospitalares e/ou ambulatoriaisiii, religiosos, professores, carpinteiros para a construção e manutenção do quartel, agricultores, dentre outros. O Decreto n. 426, de 24 de julho de 1865, deixava clara necessidade de um povoamento e da escolha dos novos sujeitos que a comporiam.

O que se trata é estabelecer núcleos de povoação, em lugares remotos centrais e despovoados, onde só a princípio podem resistir às privações, e permanecer como colonos, indivíduos habituados à obediência passiva, adquirida pelos severos hábitos da disciplina militar. A escolha desses pontos é, por via de regra, em nossas fronteiras ou em alguns centros, onde se têm acumulado vagabundos $e$ malfeitores, que ameaçam a segurança e a propriedade dos habitantes dos povoados mais próximos. Tais colônias, portanto, têm o caráter pronunciadamente militar, e embora nelas entre o elemento agrícola, ainda assim são mais que tudo colônias policiais, de segurança e de defesa, que garantem, ao mesmo tempo, no futuro, o infalível desenvolvimento de povoações [...]". iv Grifo nosso.

Destarte, a Colônia Militar de Caseros fora projetada para ser edificada às margens da Estrada das Tropas, nas adjacências da Coletoria do Pontão, possivelmente a fim de se proteger e policiar o referido posto de arrecadação tributária. A implantação de uma colônia militar possibilitaria a colonização das terras onde essa fosse estabelecida, criando um entreposto militar para resolução de conflitos internos, a serem solucionados pela força destacada dos colonos-militares.

A questão que se tornava premente de ser controlada tomava vulto e passara a exigir uma maior intervenção das autoridades provinciais, sobretudo na década de 1850, fora a problemática indígena na região norte da província. Dessa forma, a Colônia Militar de Caseros, ao ser instalada e ocupada por soldados, esperava-se, daria cabo, ou pelo menos arrefeceria os conflitos, assaltos e deslocamentos frequentes dos indígenas kaingang pela região, principalmente no que tange às parcialidades que se recusavam a permanecer assentadas nos aldeamentos provinciais: 
Os ensaios de aldeamentos nos campos do Meio, Arexi, e Pontão não tem progredido. Encontrão-se n'esses lugares algumas famílias de Indígenas sem estabelecimentos fixos, que em minha opinião não devem ser conservados, excepto o do Pontão, onde se estão medindo, e demarcando terras para uma colônia Militar de estrangeiros, fundada pelo Governo Geral, a qual muito facilitará aquelle estabelecimento. A profusão de aldeamentos não trará senão augmento de despesas, e perpetuará a rivalidade das tribos". " (Grifo nosso).

Na segunda metade do século XIX, em razão de resultados pífios das colônias e da relativa pacificação do país, houve uma reavaliação das colônias militares. O Governo Imperial imprimiu um reordenamento no processo organizacional e funcional com a intenção também de reduzir os gastos. Havia, no período, maior estabilidade política alcançada com a derrota das revoltas regenciais, maior centralização do poder, o entendimento de que a ordem política e social era fundamental para o desenvolvimento econômico e a eficácia das decisões políticas, bem como os fluxos migratórios estavam dando o tom na necessária ocupação de várias regiões que se entendiam como problemáticas.

\section{Mapa 1 - Mapa Geográfico da Província de São Pedro do Rio Grande do Sul, em 1976}

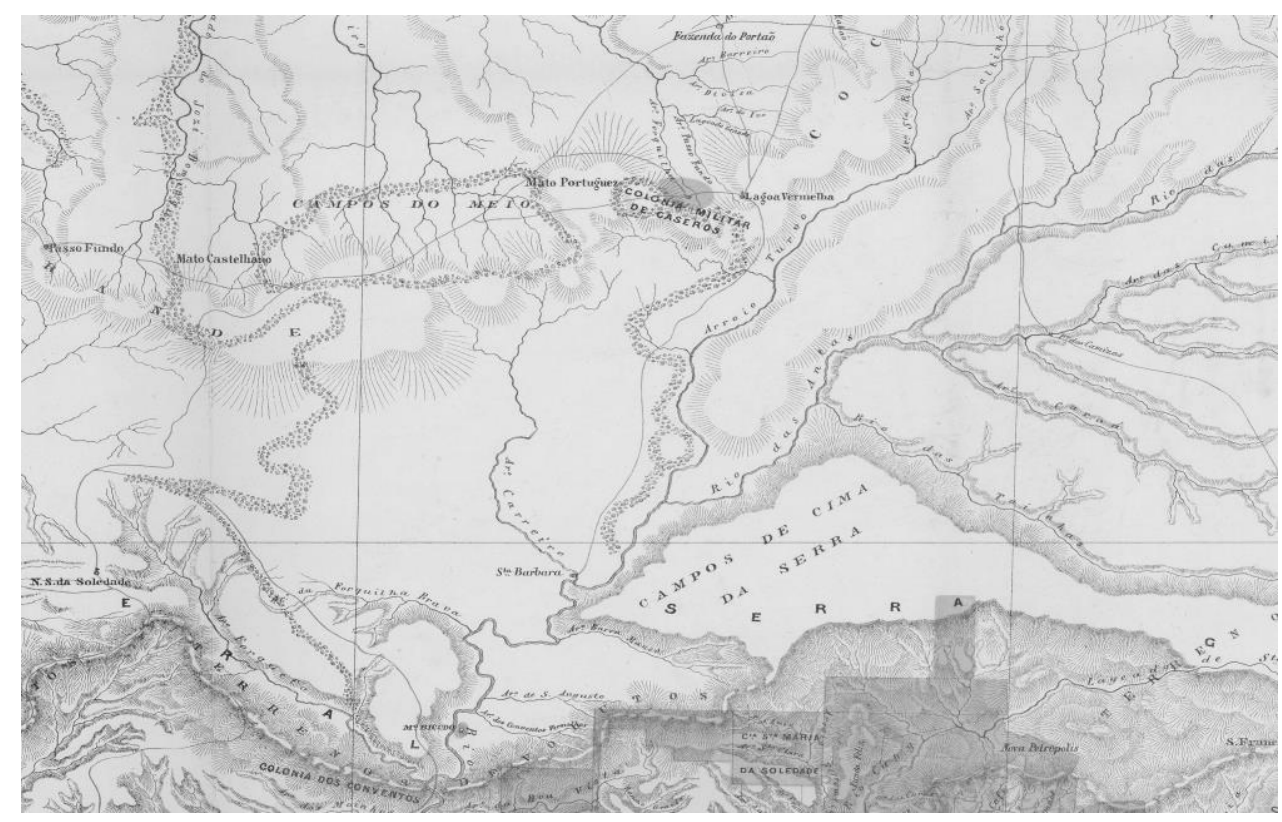

No mapa, vê-se a localização da Colônia Militar de Caseros fundada no Mato Português, bem como o Mato Castelhano, os Campos do Meio e as povoações de Passo Fundo e Lagoa Vermelha. Fonte: Biblioteca Nacional Digital da França. Disponível em: https://goo.gl/m7dEV2. Acesso em: 12/12/2016

Não podemos esquecer que o Brasil de meados do século XIX era uma colcha de retalhos, muito heterogêneo, com tensões internas, tanto no campo econômico, quanto na esfera racial e social. Os conflitos eram constantes; regionalismos, localismos e nativismos davam o tom da falta de unidade e da formação de uma consciência nacional. Essa última só seria possível pela integração das províncias, pela ocupação regrada e normatizada da terra, 
do controle centralizado do poder público nacional localizado no Rio de Janeiro (SODRÉ, 2010).

Os governantes não possuíam total conhecimento sobre o território; nação e povo precisavam se integrar; tribos indígenas totalmente desconhecidas; recursos e potencialidades não tinham como serem estimadas, não havia redes de articulação territorial entre regiões. Enfim, urgia a necessidade de conhecimento, controle e segurança do território. Colônias militares revelaram ser a maior solução. Várias delas foram implementadas no século XIX. Umas tinham função fronteiriça e outras interioranas.

\section{Mapa 2 - Localização das 26 Colônias Militares criadas durante o Brasil Império}

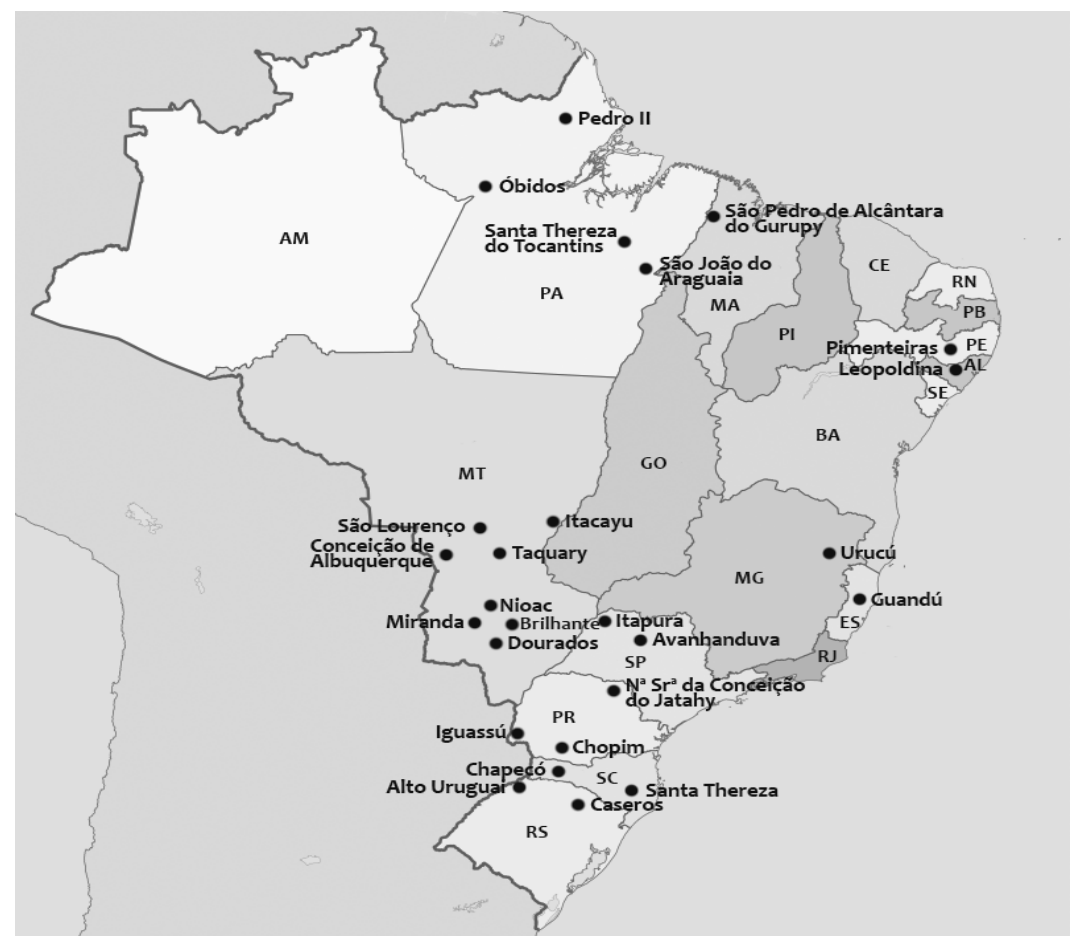

Fonte: Xavier, 2016, p. 31. Adaptado por Alex Antônio Vanin.

Como podemos ver pelo mapa anterior, no norte da província sulina, entre os matos Castelhano e Português, no atual território pertencente ao município de Caseiros (na época, pertencente a Lagoa Vermelha), instalou-se a Colônia Militar de Caseiros, em 1858. Nesse espaço, no período, havia várias parcialidades indígenas, bem como alguns estancieiros que, sob regime escravista, exploravam os amplos campos para a criação de gado, pequenos camponeses, que desenvolviam economia agrícola de subsistência e extrativismo da ervamate e madeira. Era uma região que servia de passagem para tropeiros, viajantes, 
comerciantes em geral, portanto, muito importante para a colonização e a produção agrícola, aproveitando as terras férteis, a oferta abundante da erva mate e as matas existentes para a indústria da madeira. Portanto, sob o ponto de vista da nova territorialidade, esse espaço era muito importante para os gestores públicos em nível federal e provincial.

Mas, a grande questão que se colocava era a presença indígena, principalmente em razão da constituição de duas parcialidades em conflito, tendo à frente de uma delas o cacique Braga e de outra o cacique Doble, além de pequenos agrupamentos espalhados por todo o norte da província e que migravam no interior de suas territorialidades em busca de alimentos, extração de ervas, caça, pesca e de controle de seus espaços. A localização de Colônia Militar de Caseros deu-se também em razão disso, pois era um espaço fundamental para os interesses geopolíticos e econômicos do império.

Dito isso de uma forma introdutória, o texto busca fazer um recorte temático em torno da produção agrícola dos indígenas no interior da referida colônia militar, ou melhor dizendo, da tentativa de fazer com que os indígenas fossem também agricultores, além de extrativistas e exploradores da mata para as aberturas de estradas. Essa nova função produtiva atribuída e exigida junto aos indígenas produziu contraposições, estratégias, repressões e disfuncionalidades do próprio empreendimento de controle e regramento social e territorial.

O estudo é um recorte temático de uma pesquisa mais ampla que efetuamos ${ }^{\mathrm{vi}} \mathrm{e}$, ainda continuamos a pesquisar, sobre a Colônia Militar de Caseros (1857-1878). As fontes selecionadas foram extraídas do acervo do Histórico do Rio Grande do Sul (AHRGS), principalmente de correspondências entre diretores da referida colônia e do capelão e, também, diretor dos índios e os presidentes da Província.

A intenção do artigo é dar centralidade às ações que envolveram os indígenas na produção agrícola e suas ações/reações, ou seja, os processos que tentaram produzir uma nova condição a eles, ou seja, de ser agricultor junto com os já designados a essa função no interior da referida colônia. Esse processo nos ajuda a compreender aspectos da atual demanda indígena, pois em razão dos resultados obtidos na empreitada que os envolveu na Colônia Militar de Caseros, novas parcialidades surgiram espalhadas pela região norte da Província e constituíram territórios de ocupação tradicional, sob liderança de alguns caciques, os quais, seus descendentes, atualmente, demonstram sua genealogia e a utilizam como argumentos para a reivindicação de territórios considerados de ocupação tradicional.

\section{Multifuncionalidades dos indígenas}


Grande parte das colônias militares interioranas teve na questão indígena sua presença e sentido de ser. Estabelecer-se em locais distantes de povoações, sem vizinhos e vias de acesso, tendo apenas os indígenas como povoadores, exploradores e conhecedores do território, era um grande problema para os gestores públicos das duas macroesferas políticas (imperial e provincial).

\section{Foto 1 - Destacamento da Colônia Militar de Foz do Iguaçu, no início do século XX}

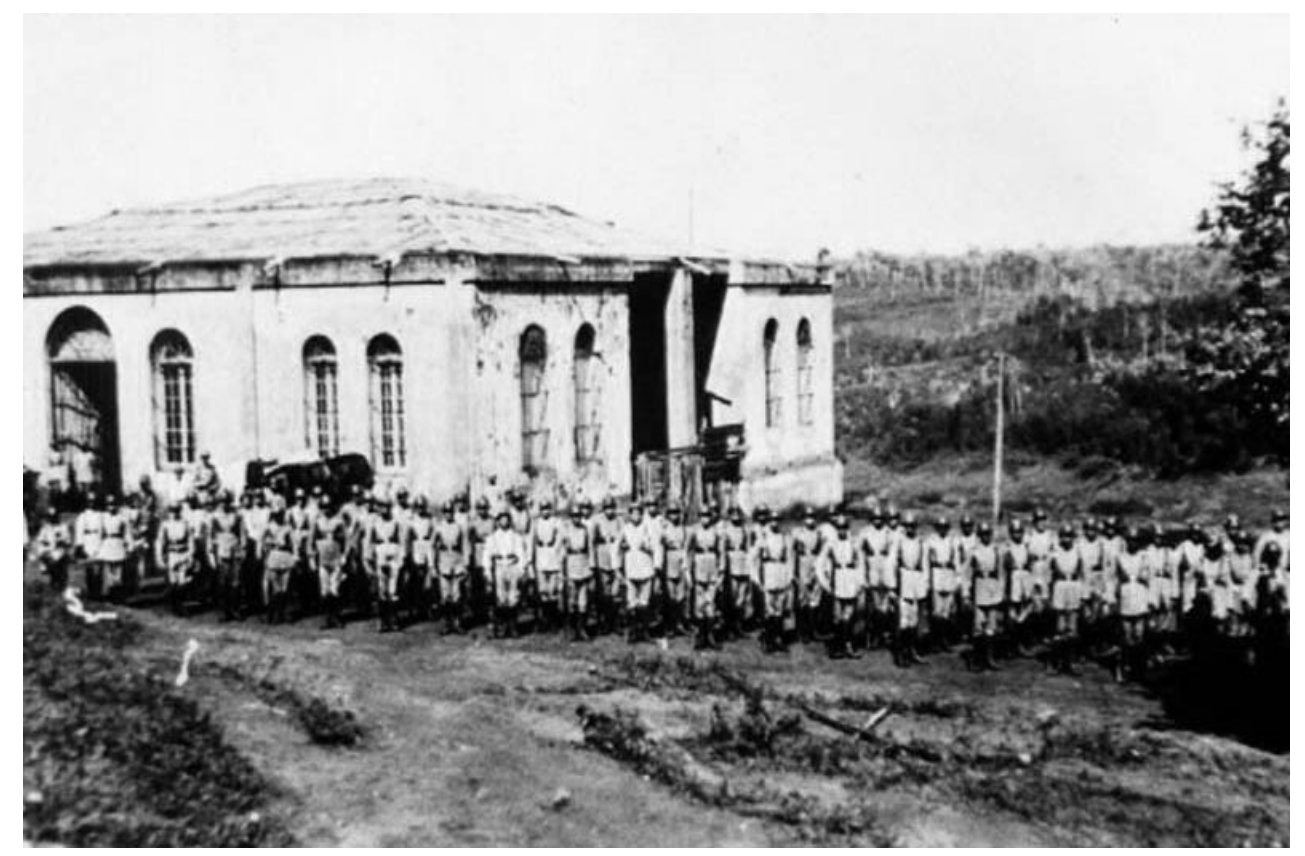

Fonte: http://www.zuccaratto.jor.br/blogs/historia-do-municipio-de-foz-do-iguacu-comeca-como-colonia$\underline{\text { militar-em-1889/ }}$

Em várias regiões do país, mas principalmente no centro-sul, em meados do século XIX, havia presença de indígenas nos territórios projetados para povoamento e apropriação das terras. Além de locais íngremes e com poucas vias de acesso, era comum nos relatos de presidentes de províncias o "problema indígena". A Lei de Terras de 1850 viabilizou a performance e o estatuto de terras devolutas em territórios identificados como de parcialidades indígenas de troncos velhos (descendentes de famílias de caciques). No entanto, para viabilizar seus objetivos, havia necessidade de agrupar e/ou retirar indígenas de seu interior (MAGALHÃES, 1875; MYSKIW, 2009). 
Essa possibilidade de implementação agrícola e militar serviria de modelo produtivo, bem como de salvaguarda para quem quisesse se instalar pelas regiões interioranas (BRÜGGEMANN, 2013). A intenção era também projetiva, ou seja, era do interesse da esfera pública de que, com o repovoamento, as sedes e colônias militares ou de comunidades no seu entorno pudessem transformar-se, no futuro, em sedes urbanas espalhadas pelo interior do país. Por isso a importância em escolher um bom lugar, produzir vias de acesso e/ou maximizar as já existentes, em particular, pela navegação de rios e picadas já abertas pelos índios. Desse modo, a utilidade dos indígenas seria múltipla, bem como seu controle. Esse último tornava-se uma empreitada difícil, mas que devia ter bom termo, pois seria também uma condição de viabilização da colônia. A proposta pública de aldeamentos surgiu ainda nas primeiras décadas do século XIX; reduções haviam sido feitas anteriormente por grupos religiosos, porém, em razão de invasões, guerras e saques por não indígenas, não foi dado sequencia (BRINGMANN, 2010; BARROS, 1980).

Agrupar indígenas em território delimitado e vigiado seria uma opção para reduzir drasticamente o que consideravam ser território seu, além de possibilitar o controle social e o livre acesso ao espaço regional de abrangência da colônia (FARIAS, 2011; FRANCISCO, 2013). Indígenas resistiam; porém, muitas lideranças foram cooptadas pela esfera pública e militar (HOLANDA et al., 2012).

Na Colônia Militar de Caseros essa questão que correlacionava indígenas com a colonização e apropriação privada da terra, era bem evidente, tanto é que o padre capelão da colônia e diretor do aldeamento indígena (Santa Izabel) que a circundava, ao saber da ameaça de extinção da referida colônia, disse que "Comissão nomeada para avaliar a situação da Colônia Militar de Caseros informou, em seu relatório que, se aquela Colônia fora criada para conter os índios do Cacique Doble, não havia razão para continuar existindo, pois os índios estavam mansos e trabalhando na agricultura" (BRANCO, 2002, p. 71). Grifo nosso.

De acordo com um relatório do final da década de 1850, está clara a determinação de que as colônias militares deveriam evitar que indígenas atacassem as populações, pois, sem esse controle seriam muito difíceis a ocupação e a produção agrícola em espaços que até então não eram povoados pelos não indígenas.

Se entendermos que as colônias militares têm por fim por um lado proteger comunicações interiores ou a população nas regiões de nossas fronteiras, e, por outro lado impedir que os selvagens ataquem populações cristãs, veremos que esta instituição ao passo que é militar tanto quanto tem por fim a defesa e segurança das fronteiras ou a segurança do cidadão que habita o interior, por outro lado é eminentemente econômica, porque promove a utilização de terrenos que sem elas 
nunca serão povoados, ou serão em período muito remoto e com muitas dificuldades. ${ }^{\text {vii }}$ Grifo nosso.

Em muitas das colônias militares, inclusive as do sul do país, a utilização da mão de obra indígena se fez útil. Além de atuar no controle e disciplinamento indígena em vários âmbitos, as ações desenvolvidas no interior e nas proximidades das colônias militares demandavam a presença e o conhecimento sobre e dos indígenas (BARROS, 1980; BRÜGGEMANN, 2013). Muitos indígenas adentraram para esse mercado de trabalho, alguns serviam para capturar desertores, que poderiam, além de colonos e/ou militares, serem indígenas. A segurança dada aos viajantes, tropeiros, comerciantes, compradores de terras, fazendeiros e colonos no sul do Brasil dependia desse controle e uso de contingentes indígenas (AVÉ-LALLEMANT, 1980; AZEVEDO, 1984).

\section{Aldear e controlar}

Os Kaingang que habitavam o Planalto Meridional interagiam no território a partir de suas parcialidades, dos contatos e usos da mata e dos campos, de sua circulação e deslocamento pelos seus territórios e/ou seu sentido de territorialidade, alterando o modo de habitação entre aldeias fixas e acampamentos que se constituíam sazonalmente, principalmente em razão dos recursos ambientais e naturais existentes (clima, chuva, fontes, rios...), atividades agrícolas, hortas, caça, coleta, ervas, também para visitar parentes, produzir laços matrimoniais, etc. Esse processo não configurava um mero nomadismo e, sim, uma estratégia econômica, étnico-ambiental, social e política (HOLANDA et al., 2012). Essa é a noção de território indígena, de mobilidade espacial num espaço histórico de deslocamentos coletivos (LAROQUE, 2007). Desse modo, acampamentos e aldeias faziam parte da dinâmica de mobilidade, recursos, poder, parcialidades indígenas, transmissão de saberes, proteção e vínculos matrimoniais.

\section{Mapa 3 - Locais de ocupação tradicional Kaingang no Brasil Meridional}




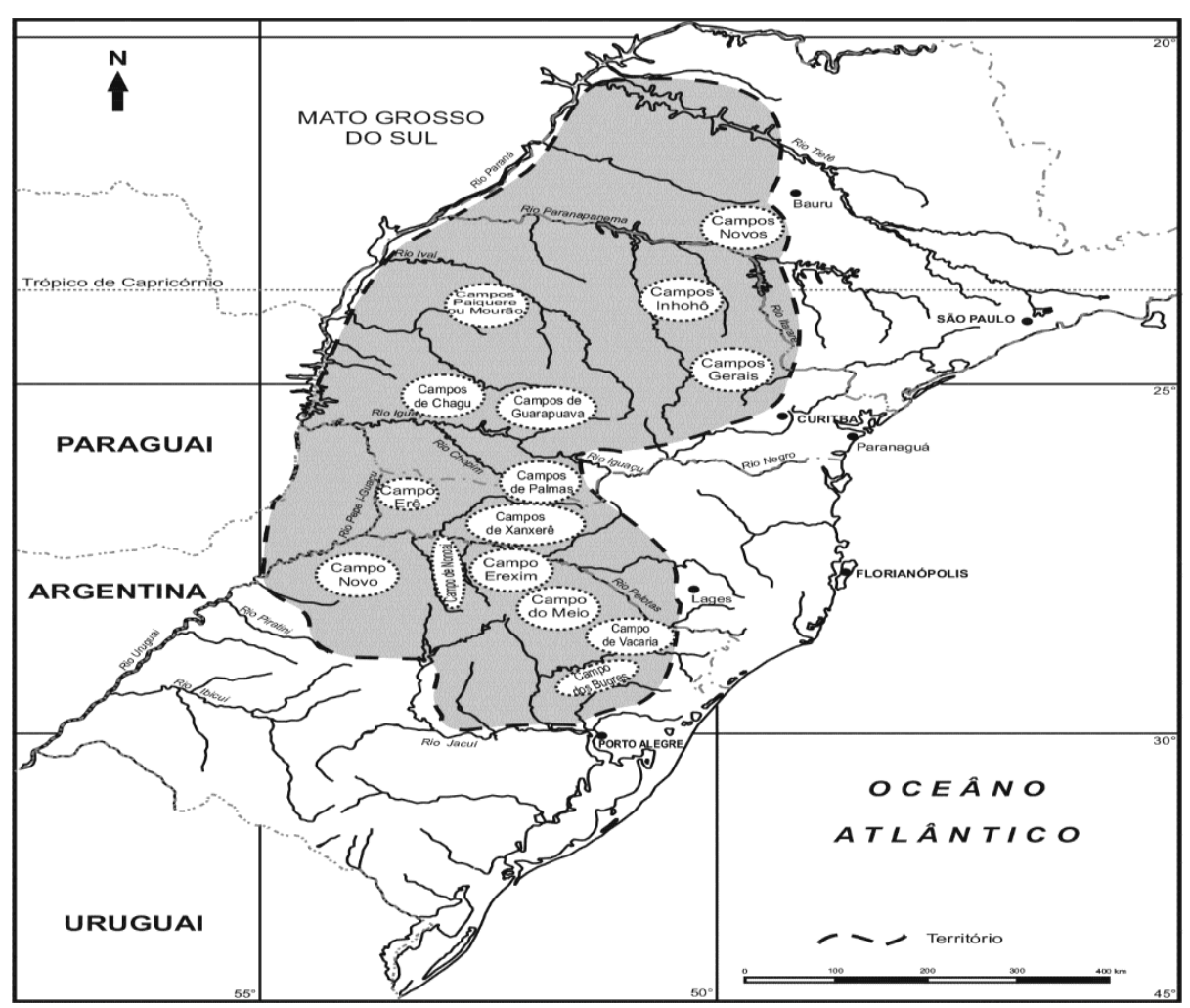

Fonte: Laroque, 2007, p. 36.

É importante lembrar que a região centro-norte da Província sulina, em meados do século XIX, situava-se no âmbito das políticas de terras devolutas (fruto da Lei de Terras) e aptas para a colonização. Os indígenas presentes nesse cenário, em geral, da etnia Kaingang, foram induzidos aos novos aldeamentos impostos pelo governo imperial, para a formação de núcleos para imigrantes através de processos de colonização (GOLIN, 2007; BECKER, 1995). As terras que pertenciam às ditas "hordas selvagens" tornar-se-iam, a partir de então, aptas e necessárias à colonização e integração da nação (SIMONIAM, 1995).

Durante todo o século XIX afinou-se um discurso no interior da esfera governamental em torno da necessidade de aldeamentos. Ainda no início do referido século, as Cartas Régias (1808 e 1809) de D. João VI, autorizavam as "guerras justas" no sentido de que os indígenas não poderiam ser um empecilho ao povoamento do interior do país (LAROQUE, 2007) e, portanto, se necessário for, usar-se-ia a força de repressão e/ou seu consequente extermínio. Isso tem provocado muitos conflitos, principalmente nos Campos Gerais (na região conhecida hoje como Campos de Palmas, no denominado "Paraná Antigo") e em vários outros territórios entre indígenas e pecuaristas, colonizadoras, aliadas ao poder provincial. Esse processo legitimou ações em torno de noções como civilização, domesticação, selvagem, contato, pacificação, assimilação e intrusão. Políticas de intrusão em terras indígenas foram efetivadas 
pela esfera pública, em particular, no sul do Brasil, as quais estavam ainda pouco povoadas, para, justamente, produzir os conflitos e legitimar a ação pública de esbulho dos indígenas.

A província sulina, no horizonte desse processo político, buscou implementar a constituição de aldeias indígenas, principalmente no centro-norte (LAROQUE, 2000). Os toldos de Nonoai e Guarita surgem em 1846 como fruto disso. Outros aldeamentos foram programados, mas não plenamente efetivados, como foi o caso de Campo do Meio, esse, próximo à Colônia Militar de Caseros. Missionários jesuítas e franciscanos foram inseridos no interior dessas parcialidades, bem como nomeados diretores leigos nas referidas aldeias e em regiões ainda de grande presença de grupos que resistiam em aldear-se, em particular, nas regiões dos territórios de Passo Fundo, Lagoa Vermelha, Vacaria e Encosta da Serra, u seja, boa parte do centro-norte da província sulina.

O engenheiro agrimensor Mabilde foi designado para a região dos matos Castelhano e Português para construir estradas e facilitar, com isso, o transporte de gado e mulas, bem como a colonização nessa região. Em seus escritos ele coloca que, "entre os campos de Passo Fundo e os de Vacaria - matas essas que abrangem o Mato Castelhano, foi aqui o ponto em que se concentravam os Coroados - existia uma grande tribo da Nação Coroada, da qual era cacique principal o Coroado Braga" (MABILDE, 1983, p. 165). Nesse território, registram-se lutas indígenas por apossamentos de pinheirais, terras de caça, coleta e extração de erva-mate, tentativas de cooptação, concessões e promessas realizadas pela esfera pública provincial para que houvesse aldeamentos.

Ao que se sabe, o cacique Braga aceitou as negociações e se estabeleceu no Aldeamento de Pontão, em 1850, porém, logo em seguida, transferiu-se para o Campo do Meio (MABILDE, 1983). Segundo Becker (1995), sua parcialidade migrou, na década de 1870, para onde, posteriormente, no início do século XX, constituiu-se a Reserva do Ligeiro. Ambos os caciques evitavam localizar-se em territórios muito próximos justamente para não desencadear confrontos (KUJAWA; BADALOTTI, 2016). Quanto a Doble, foram várias as promessas e tentativas de aldeamento e deslocamentos, porém, sua inimizade com Braga produzia também inamistosidades com outros líderes em aldeamentos já constituídos, como é o caso de Nonoai e Guarita. Parcialidades indígenas localizadas em Caseros, Pontão e Campo do Meio circulavam pelos territórios e revelavam ser, em meados do século XIX, espaços de sazonalidade de presença indígena. Na narrativa de Pezat, "as tentativas de criação de um aldeamento para reunir índios da região dos Campos de Cima da Serra, liderados pelos caciques Braga e Doble, fracassaram. Os aldeamentos do Campo do Meio e de Caseros 
tiveram curta duração, sendo abandonados poucos anos após serem criados" (PEZAT, 1997, p. 270).

\section{Mapa 4 - Área de ocupação e deslocamento indígena no norte do Rio Grande do Sul - século XIX}

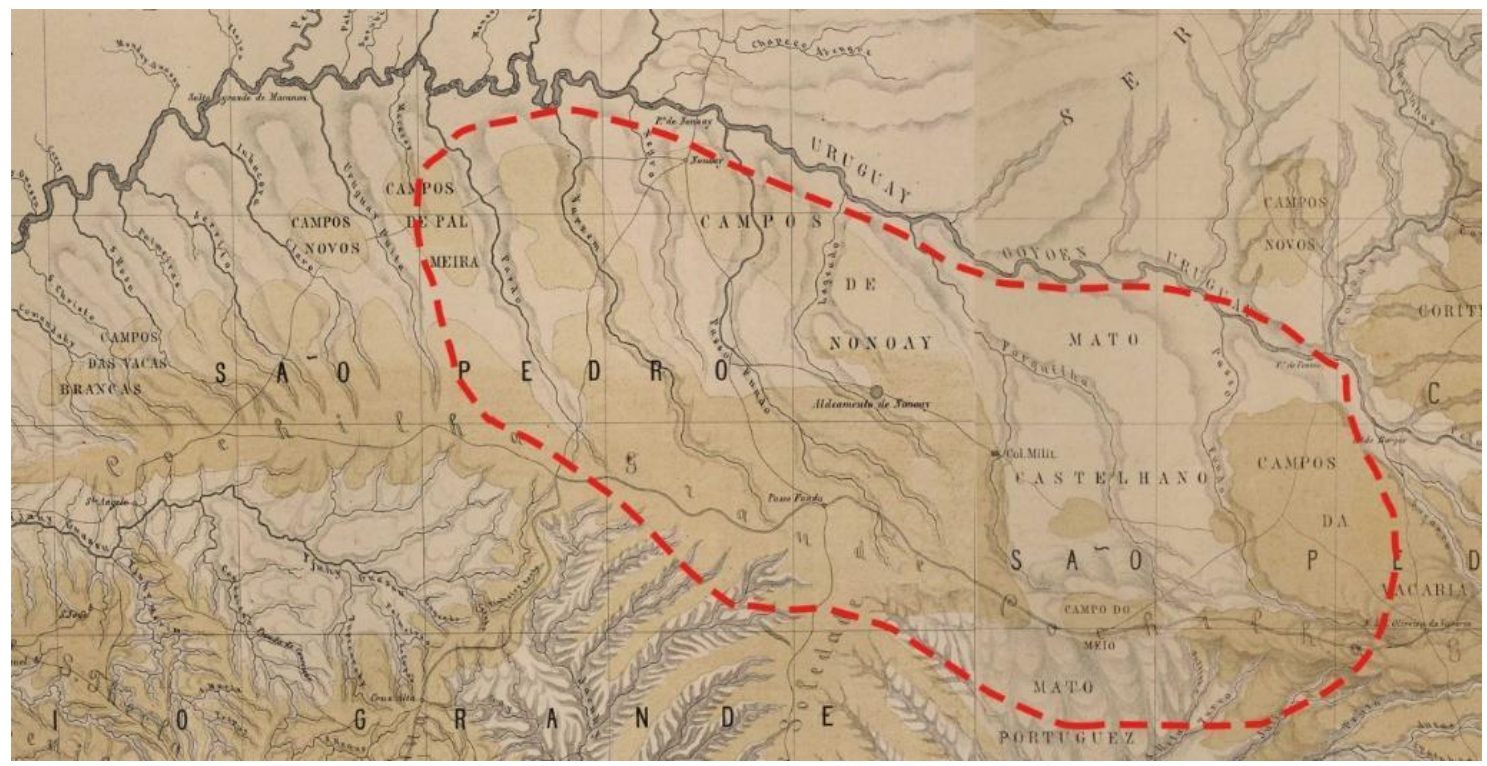

Fonte: SCHULTZ, 1863. Mapa da Província de Santa Catarina do Império do Brasil. Na área destacada, é possível visualizar as localidades de deslocamento Kaingang no norte da província, como os Campos do Meio, de Nonoai, Palmeira, Passo Fundo e Vacaria, bem como a Colônia Militar de Caseros e os Matos Português e Castelhano. Fonte: Biblioteca Digital Luso-Brasileira. Disponível em: https://goo.gl/rCVfuY. Acesso em 15 out. 2018.

Para a nossa questão específica, é interessante continuar informando que cinco anos antes da constituição da Colônia Militar de Caseros, em 1853, o Presidente da Província havia acenado para a constituição de um aldeamento na região e solicitou ao Cacique Doble que escolhesse um local, como compensação e "reconhecimento ao auxílio que Doble e seus índios deram, derrotando o grupo do Índio João Grande e de um escravo fugido de nome desconhecido, que haviam assassinado toda a família Menna da Colônia Mundo Novo (hoje Taquara)" (BRANCO, 1993, p. 69). Havia a promessa de alimentos, vestimentas, pinhais, cavalos e armas para que Doble fosse fortalecido em termos de poder e de condições de vida junto à parcialidade que comandava. No Relatório, onde consta a fundação do Aldeamento Santa Isabel, em 1859, narra-se que

O estado em que paravam os indígenas das tribos dos caciques Doble e Capitão Chico ("nariz comido"), desde que tomei posse da administração desta Província atraiu minha atenção. Nomeei o cidadão Alberto Marques de Almeida para diretor destes infelizes e pedi ao governo imperial que os tomasse sob sua proteção. [...]. $O$ governo Imperial criou uma colônia Militar no Distrito de Lagoa Vermelha para a proteção da população dos lugares vizinhos, e autorizou-me para mandar ali um missionário catequizar esses infelizes. [...]. (Apud BARBOSA, 1989, p. 12 e 13). Grifo nosso. 
O Aldeamento Santa Isabel constituiu-se a partir de uma confluência e junção de indígenas espalhados pela região; seus vários espaços de fixação também revelam isso, ou seja, aproximavam-se de agrupamentos indígenas já existentes e/ou de espaços que não havia demanda pela apropriação das terras por não indígenas. $\mathrm{O}$ seu primeiro diretor em 1859 , Alberto Marques d'Almeida, informa o Presidente da Província que havia muitos indígenas espalhados pelo amplo território do Mato Castelhano e que havia dificuldade em aldeá-los: "[...], hontem cheguei a esse aldeamento trasendo cento e poucos indígenas que com muita difficuldade e grande despesa consegui recondusi-los [...], amanhã sigo para o Mato Castelhano em busca do resto da tribo que lá se acha refugiado". viii

Os indígenas migravam em busca de recursos para a subsistência, principalmente o pinhão, o peixe, o mel, as frutas, o milho, a caça, etc. Nesse sentido, a noção de território ganha dimensão coletiva, ou seja, de um grupo e se constitui em razão de múltiplos fatores (genealógicos, recursos naturais, de poder e liderança, de roçados, de ligações espaciais, de subsistência alimentar, mercado matrimonial, etc.). Em 1842, o Tenente Coronel Vidal Jozé do Pilar escreve uma carta ao Brigadeiro e General em Chefe do Exército, Jozé Maria da Silva Bitancurt, que estava acampado e guarnecendo a entrada do Mato Castelhano, informando que nessa região havia necessidade de proteção aos que se deslocavam através dela e para os que decidiam constituir morada.

[...], tenho a honra levar a presença de V. Exa, a lista das praças que se achão guarnecendo a entrada do Mato Castelhano. [...], ali os conservo, por serem próprios para o lugar, em razão dos gentios que muito ameação aquele lugar. [...], o lugar he bastante perigozo, em razão dos bugres que inda forão vistos no campo pela costa da serra para mais de duzentos [...]. ${ }^{\text {ix }}$ Grifo nosso.

A abertura de novas estradas e de seu encurtamento eram condições fundamentais para a mobilidade de pessoas e mercadorias. As políticas de aldeamentos de meados do século XIX até as primeiras décadas do século XX, como já vimos, objetivavam reduzir e delimitar as áreas até então identificadas como territórios indígenas, liberar as terras e pacificar os índios, romper com as denominadas "hordas errantes e selvagens", ou seja, sua movimentação pelos territórios (HENSEL, 1828) e, com isso, a abertura de estradas em espaços ainda impenetráveis pelos não indígenas se faria possível.

Foto 2 - Abertura de estradas no final do século XIX e início do século XX no norte do RS 


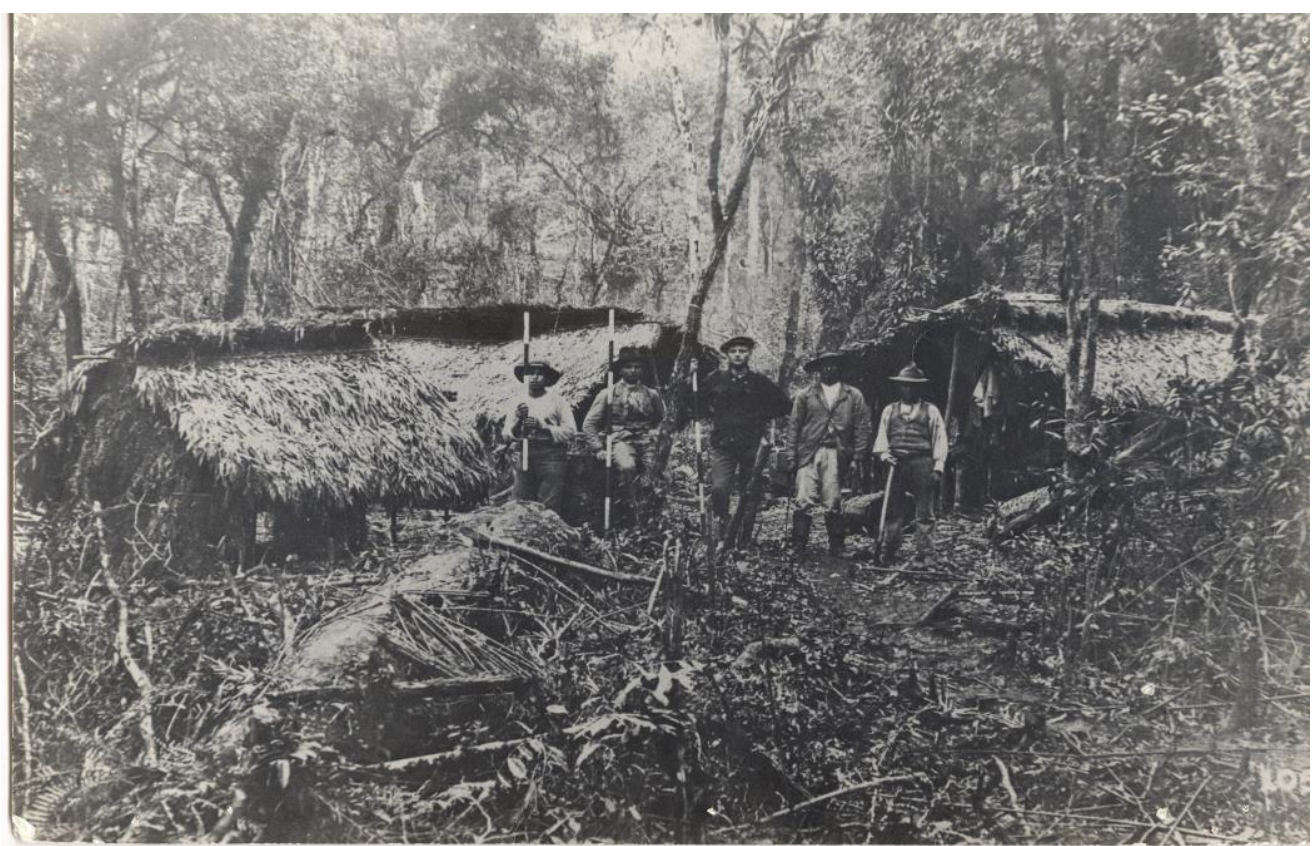

A abertura de estradas no norte da província sulina sempre foi uma preocupação dos governantes a partir da metade do século XIX. Domínio territorial, encurtamento de distâncias, controle social, viabilização de povoamento e aquisição de terra, dentre outros aspectos, fundamentavam essa ação.

Fonte: Arquivo Histórico Juarez Miguel Illa Font, Erechim/RS.

\section{O Aldeamento Santa Isabel}

Em meados do século XIX, o cacique Braga dominara, junto com as tribos subordinadas, boa parte da região noroeste do Rio Grande do Sul (Becker, 1995). Entre 18401850, Doble, que era seu subordinado, lutou contra ele pelo domínio político na região entre os campos de Passo Fundo e Vacaria (STANGERLIN, 1989; LAROQUE, 2000). Segundo Simoniam (1995), o cacique Doble, em conflito com a liderança do cacique Braga, deslocouse, primeiramente, do denominado Campo dos Bugres, região que posteriormente seria incorporada pela colonização italiana, para as proximidades da Colônia Militar de Caseros, onde, inclusive, segundo a autora, prontificou-se auxiliar na sua defesa e vigilância em troca de alimentos, vestimentas, pagamentos e outras promessas que lhe foram feitas.

A parcialidade do toldo Santa Isabel resulta de rivalidades entre lideranças indígenas, concorrência pelo poder e territórios, das circularidades territoriais e descendências dos chamados "troncos velhos" e das promessas feitas ao cacique Doble pelo governo da Província. Como já vimos, o referido toldo circulou por vários espaços na região norte e nordeste da província sulina tendo, em boa parte de sua história, a liderança do cacique Doble. Durante alguns anos, esse agrupamento esteve situado em terras contíguas à Colônia Militar de Caseros, porém, como já mencionamos, sua circularidade territorial era ampla no interior 
dos matos Castelhano e Português, bem como na região do vale dos rios Antas, Taquari e Jacuí (norte e nordeste da Província).

O Aldeamento Santa Isabel, deslocava-se da proximidade ao interior da Colônia Militar de Caseros; isso fazia parte da sua estratégia. Ao mesmo tempo em que os indígenas da parcialidade do cacique Doble poderiam se sentir um tanto protegidos das investidas do grupo do cacique Braga, tornavam-se vítimas das estratégias de assimilação e integração das políticas de governo aplicadas pelas ações da referida colônia, ou seja, de inseri-los ao seu horizonte produtivo, fornecer seu sustento, insumos básicos, acostumá-los à vida sedentária, utilizar ferramentas para as atividades da agricultura. Com isso, seria uma espécie de ante-sala para os processos de aldeamentos que se desenhavam por todo o território brasileiro e, em especial, o sulino.

Primeiramente, os diretores da Colônia eram também responsáveis pelos índios; o capelão e diretor dos índios, que poderia ser uma só pessoa, surgem alguns anos depois do início dela. Os dois primeiros diretores ${ }^{\mathrm{x}}$ narraram em seus relatórios a dificuldade nas relações com os indígenas e, demandavam a presença de um diretor que pudesse atuar diretamente com eles, coordenar as lavouras e também tivesse conhecimento de construção e, que fosse padre.

[...], sei que nessa capital, existe um padre que tem as necessárias habilitações; ora ele se quisesse occupar o lugar do Capellão, Mestre de Obras, e director das lavouras no que é tambem pratico. Seria isto de uma importância incalculável: [...], e me parecendo que, com um ordenado de dusentos mil reis, por mez, elle entraria em ajuste com V. Ex [...]. ${ }^{\mathrm{xi}}$

Em agosto de 1862, foi indicado o Pe. Branco como diretor dos índios, o qual exerceu uma grande influência nas ações dos indígenas na região. “[...]. Accuzo a recepção do officio de V. Ex [...], em que me ordena que passe a direção dos índios ao reverendo Padre Capellão Antonio de Moraes Branco [...], entregando-lhe uma relação nominal de oitenta e seis índios que se achão aldeados nesta Colonia". xii

No final de 1862, o Pe. Branco escreve ao Presidente da Província de que havia mais de 100 indígenas aldeados e que, num breve tempo, iria reunir mais 27 que estavam na redondeza, "nos matos do Pontão". Porém, insiste ele que os indígenas querem soldos, com isso aceitam mais facilmente o aldeamento.

Em 1863, segundo relatórios do Padre Branco, que, no período, dirigia os indígenas aldeados próximos da Colônia Militar de Caseros, a dependência alcoólica vitimava muitos deles. O referido religioso denunciava os maus tratos dos soldados e do diretor da Colônia em relação aos índios, principalmente pela sua resistência em alterar seu horizonte cultural, 
principalmente na produção agrícola (que era fundamental para a Colônia e ampliaria os braços nas lides da roça e reduziria os dos militares e colonos), nos altos custos alimentares e financeiros para mantê-los, bem como sua intensa dispersão territorial. Conflitos, em razão disso, eram frequentes; muitos deles estão nos relatos do Pe. Branco.

[...], o Cacique Doble nutria vivos desejos de receber soldo, tanto esse como seus oficiais, e isto por promessa do Tenente Hortencio, mas fazendo eu lhe ver que os soldados do Exército que percebem soldo por que vão guerrear com o inimigo, e que a sua gente não podia ser paga sem que fosse tambem expôr-se ao perigo, desistio logo do proposito, dizendo que sua gente é pouca e não quer que morra no campo de batalha. .iii $^{2}$

O número de indígenas no referido aldeamento oscilava muito em razão de dispersão, incorporação, doenças e epidemias, conflitos internos no grupo, perdas de vida em batalhas com parcialidades inimigas e aldeamentos de alguns membros em outros espaços, em particular, no Toldo de Nonoai e Fachinal.

Casas de indígenas eram incendiadas quando de algum tipo de doença acometia a família que nela residia; não havia condições de tratamento, desse modo, a fuga no mato, a junção no interior de outras parcialidades onde poderiam usar seus saberes nas curas, acabava sendo uma estratégia, porém, não tão eficaz, pois eram doenças desconhecidas deles. Em meados de 1867, o Aldeamento Santa Isabel foi tomado novamente por doenças, sendo que 49 indígenas haviam morrido. Pe. Branco reclamava que os indígenas foram deixados à própria sorte, sem atendimento médico, sem medicamentos a não ser os seus e que demonstravam ser pouco eficazes. Ele pede ao Presidente da Província que autorize a presença do médico da Colônia.

Peço pois a V. Ex ${ }^{\mathrm{a}}$, que, condoendo-se da sorte precaria dos Indios, se digne ordenar ao Cap. Diretor d'aquela colonia, que o medico da mesma continue a prestar-se com as vizitas e medicamtos aos dos Indigenas, como outr'ora. Eu tenho uma grande botica Homeopathica, e applico esses medicamentos a quem delles necessitar; mas já sinto falta de medicamentos, e alem disso não sou profissional, e temo perder os doentes quando em estado grave. ${ }^{\text {xiv }}$

Frente a essa questão de pragas e doenças, que promoviam dispersão e/ou dificuldade de manter os indígenas aldeados e da forma pacífica, bem como porque "ali habitavam unicamente indivíduos dissolutos e vadios, vivendo errantes os índios e perturbando a disciplina e os trabalhos da Colônia Militar de Caseros" (ROCHA, 2005, p. 86), o Presidente da Província escreve para o Ministro da Guerra para extinguir o Aldeamento Santa Isabel em razão dos altos custos, doenças e da dispersão dos indígenas, fatos esses que ocasionam muitos problemas para o diretor dela.

O Diretor parcial nomeado para o citado aldeamento, cuidando mais em seus interesses do que do bem estar dos índios que llie haviam sido confiados deu causa 
a que fosse mandado ex-tinguir o citado aldeamento em 25 de fevereiro de 1861, visto que poucos eram os índios que ali permaneciam, no entretanto que os despesas mensais com alimentos etc eram consideráveis. ${ }^{\mathrm{xv}}$ (Grifo nosso).

No entanto, extinguir o aldeamento significava reduzir a importância e os objetivos da referida colônia, além do mais, os índios dispersos e não aldeados poderiam significar grande perigo e expressar as fragilidades de defesa e a precariedade do empreendimento colonial localizado na região. O aldeamento não foi extinto como havia solicitado o Presidente da Província, ao contrário, permaneceu sob a direção do Pe. Branco, o qual passou a imprimir um amplo controle sobre os indígenas. Ele exercia várias funções para além da catequese e de outras dimensões e rituais religiosos, dentre as quais, a tentativa de inserção deles nas atividades agrícolas como expressão das exigências e cobranças do diretor da Colônia.

\section{A enxada e os indígenas}

A agricultura era fundamental no processo de configuração das colônias militares. Não era apenas a produção agrícola, ainda que fosse central, mas todo um processo que culminava nela: desbravamento e interligação territorial, presença de colonos, possibilidade de obtenção de um título de propriedade, economia doméstica, atração de novos proprietários e produtores no entorno do empreendimento militar, promover a circulação do dinheiro no interior e exterior dela, empregar trabalhadores temporários e que viviam na redondeza, inserir indígenas na atividade, etc. (BRÜGGEMANN, 2013).

O governo provincial orientava os diretores de colônias para que diversificassem a produção e aumentassem cada vez mais as safras, no caso do sul do Brasil, com feijão, milho, trigo, erva mate, fumo e seus produtos do consumo doméstico, ou seja, para sua própria subsistência; insistia também para que fossem melhoradas as técnicas de produção, evitassem perdas na estocagem e comercialização, aproveitassem os preços melhores. Nesse sentido, não era incomum colonos receberem compensações financeiras da direção da colônia em razão de sua otimização agrícola (BARROS, 1980; BRÜGGEMANN, 2013).

A agricultura demandava sinergias territoriais, ou seja, necessitava de ofertas de sementes e insumos, bem como de uma rede de comerciantes e/ou consumidores para absorver o excedente produzido e viabilizar transações mercantis. Ela induzia a abertura de canais de circulação de pessoas e de mercadorias no horizonte externo. Então, para viabilizar o circuito mercantil da produção, circulação e consumo havia necessidade de estradas, interconhecimento regional, domínios de saber nos cultivos e nas transações comerciais. 
Pontos de estrangulamentos se apresentavam em razão da inexistência de sementes de qualidade ou suficientes para o plantio, falta de conservação do produto, total ausência de conhecimentos técnicos dos que se tornavam colonos por ocasião de sua presença em colônias militares, ausência de compradores, exploração de comerciantes (pela redução do preço pago aos produtores e/ou aos diretores das colônias militares), inexistência de estradas e de consumidores próximos, faltas de cercas e potreiros para enclausurar o gado e evitar que esse atacasse as plantações, bem como da incapacidade de controlar a entrada de gado criado as soltas na redondeza.

Diretores da Colônia e dos indígenas buscavam inserir os "silvícolas" na produção agrícola, porém, a dificuldade demonstrava ser imensa, pois esses reagiam frente a essa investida. Seguindo nessa intenção, logo no início da Colônia, em 1858, uma correspondência do diretor revela essa intenção. "Eu ofereço-me para dirigir este trabalho, não somente pelo interesse de fazer algum bem a este lugar, mas ainda por que convém como pretendo empregar os índios no serviço, donde espero torná-los possuídos a ambição e mais depressa habituá-los ao trabalho". ${ }^{\text {vi }}$ Grifo nosso.

Em outra circunstância, o Presidente da Província informa que foram providenciadas obras para o desenvolvimento da Colônia, mas, principalmente, queria ver os índios no trabalho, em particular, na reabertura de estradas. "[...], algumas obras forão desde logo autorisadas, não só para o desenvolvimento do aldeamento, como para ir habituando os indígenas ao trabalho. A mais importante é a reabertura da estrada do Mato Portuguez, segundo informa o respectivo director". ${ }^{\text {vii }}$ Em outra passagem também a referência aos indígenas é expressa. “[...], a Estrada Velha fora abandonada á mais de 20 annos, [...], ambas podião ser aproveitadas e melhoradas com pouco dispendio dos cofres públicos, se nesses trabalhos fossem aproveitados os serviços dos indios". xviii Esse processo fez com que indígenas manuseassem as ferramentas dos não indígenas, adotassem hábitos alimentares diferenciados e utilizassem o dinheiro, roupas e bebidas que não lhe eram comuns (VIANNA, 2000).

A insistência e as tentativas do Diretor dos Índios para aldeá-los e fazê-los trabalhar na roça era intensa. Alguns caciques e/ou lideranças de parcialidades, que viviam e/ou circulavam pelo entorno regional da Colônia, não aceitavam o aldeamento, mas expressavam desejo de produzir na agricultura e, estrategicamente, solicitavam ferramentas. "[...]. Aqui esteve o Capitão Chico do Campo do Meio, e me declarou que não vem aldear-se aqui [...]; disse-me mais que não quer fornecimento, porque plantou o ano passado, e tem porcos e aves;

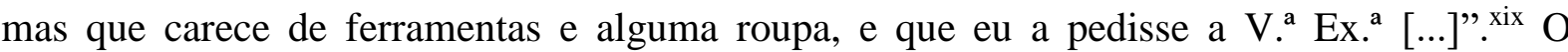


referido diretor se ressente em não poder aldear o grupo do Capitão Chico, pois além de reconhecer seu apreço e vice-versa, havia um considerável contingente de indígenas em sua parcialidade: “[...], homens 20 , mulheres 25 , crianças menores de 10 anos $27=$ total 74 ”. xx

Em 1862, cacique Doble solicita ao Diretor da Colônia Militar de Caseros sua inserção, juntamente com seu grupo, no interior da referida colônia, no espaço onde estava o aldeamento antigo e promete dedicar-se à atividade agrícola.

Participo a V. Exa. que no dia 20 do pretérito, apresentou nesta Colônia o Cacique Doble, outrora aldeado no Aldeamento de Santa Isabel, contígua a mesma Colônia e extinta pelo Emo. Sr. Conseíheiro Antão; com o capataz Doble, Cliico, Capitão Domingos, Chico Brigadeiro e toda a sua tribo declarando-me que queria aldear-se dentro dos limites da Colônia e dedicar-se com sua gente ao serviços agrícolas etc. ${ }^{\text {xi }}$ Grifo nosso.

Porém, o diretor não alimentava muita esperança de que isso fosse possível, pois conhecia algo da história e índole de Doble e, em razão disso, seria muito difícil inseri-lo nas atividades agrícolas e tê-lo numa perspectiva sedentária no interior do Aldeamento. Ele constata o que ele previa e pede ao Presidente da Província que dê outro destino ao cacique Doble, pois além de não trabalhar, vive errante, dando maus exemplos aos seus comandados, além de que não atender às ordens da direção da Colônia. “[...]. Todo o Aldeamento se acha em páz e os indígenas empregados mais ou menos no trabalho - a excepção do Cacique Doble que não tem parada effectiva [...], julgo prudente $\mathrm{V}$. Ex ${ }^{\mathrm{a}}$ providenciar para q' se dê a este Indio um destino qual quer". xxii

A demonstração de alguns caciques na inserção das atividades agrícolas da Colônia Militar de Caseros é expressão dos limites impostos à sobrevivência na região, principalmente em períodos de carência do pinhão. Para manter suas parcialidades, algumas lideranças tinham a obrigação de garantir o sustento e, isso, em razão da intrusão dos não indígenas, das políticas de aldeamentos e as resistências que eles imprimiam, bem como a demarcação territorial de outros grupos, era dificultada. A estratégia da demanda pelo espaço agrícola da referida colônia militar dá-se nesse contexto.

Para os indígenas inseridos no aldeamento da Colônia, a não inserção no trabalho agrícola dificultava a obtenção necessária à alimentação do grupo, fato esse que os tornava dependentes da ração proveniente da direção dela. Para o diretor dos índios, poderia significar a perda do cargo ou expressão de inoperância. Nesse sentido, havia ameaças: "[...] hoje me entregou o ofício de v. Em. de 4 do mês passado em que ordena que de agora em diante só se abonará etape aos índios menores, e as pessoas que não pudessem de todo trabalhar, o que cunprirei". Os índios ficaram sumamente tristes, "porque atualmente não tinham para sua subsistência mais que a caça e, essa em pouca abundância e dispostos a retirarem-se para 
outros lugares onde ela abunda, me tem sido mui penoso demovê-los desse propósito: mas felizmente ainda aqui se conservam". xxiii

Em outros momentos, o Pe. Branco, que era o diretor dos índios, explicava que, o fato dos índios dedicarem-se algum tempo na roça, não podiam caçar, desse modo, havia carência de alimentos, pois o ciclo agrícola dos produtos não permitia a oferta de alimentos da noite para o dia e as condições de conservação dos alimentos da safra anterior eram precárias. O referido representante dos índios reclamava sempre da inexistência de ferramentas e que isso também dificultava a presença dos indígenas nas atividades agrícolas, de derrubadas de mato e de confecção da erva mate. Justificando a despesa acrescida do Aldeamento, ele narra ao Presidente da Província que

[...]. A despesa é mais crescida do que o desejado; porém duas razões militam para que isso se dê: a primeira é porque os índios empregados no serviço da roça não se tem empregado na caça; e a segunda porque a estação em que nos achamos é para eles a mais precária visto não ser tempo de milho verde, feijão, abóbora, pinhão, frutas [...]. Os índios não têm tido a ferramenta precisa para o serviço da roça; apenas tem dez foices que me emprestou o Ten. Diretor desta Colônia, e cinco machados. ${ }^{\text {xiv }}$ Grifo nosso.

O Pe. Branco reclamava junto ao diretor da Colônia ou diretamente ao Presidente da Província em torno da necessidade de soldos para os índios, pois sem esses, era difícil manter os índios agrupados no território sob seu comando, já que esses saiam para buscar alimentos, dispersavam-se pela região, fugiam para compor outras parcialidades e, a possibilidade de saques e correrias era muito grande. Casos de correrias na região serviam para fortalecer seus argumentos e demonstrar perigo e descontentamento, além de exteriorizar a inoperância e os limites da Colônia.

Essa realidade presente após quase 10 anos de efetiva colônia militar revela falta de controle dos indígenas, o descontentamento desses, a ausência de controle e prevenção de conflitos, a precariedade de condições de defesa e o reduzido contingente de militares frente ao dos indígenas na região. Indígenas reagiam ao controle impresso pelos diretores da Colônia e do aldeamento, à falta de alimentação, de liberdade, de possibilidade de sair para caçar, coletar e visitar outros agrupamentos, etc.

O cotidiano da Colônia produzia ações e relações entre indígenas e não indígenas; gratificações e contraposições estavam em jogo; barganhas, dependências, liderança, poder, rivalidades, etc., enfim, um campo de disputas e estratégias entre indígenas, em particular o cacique Doble e sua parcialidade, e as demais, em especial, a do cacique Braga, os aldeamentos forçados, a necessidade de manter uma comunidade de interesses entre o 
primeiro cacique e os diretores da Colônia, os limites e necessidades de ambos, aglutinavam um amplo espectro relacional.

O jogo de poder no interior da Colônia e do Aldeamento expressava-se no regramento social e na tentativa de integração dos indígenas, em particular na atividade agrícola. Entradas e saídas de indígenas do/no Aldeamento era parte do cotidiano e precisavam ser administradas para evitar maiores conflitos. Em 1865, segundo o Relatório, “apresentaram-se ao diretor da Colonia 25 homens e 23 mulheres indígenas, declarando ser de sua intenção aldearem-se dentro dos limites da Colônia e aplicarem-se aos trabalhos agrícolas, pois não queriam transferir-se para Nonoai” (BARBOSA, 1989, p. 14). Muitas vezes as entradas se davam em razão de conflitos entre parcialidades, de inexistência de outras alternativas, pois a precariedade e os limites vividos no aldeamento de Nonoai, a repressão de não indígenas nas matas e em terras já apropriadas por esses, expressavam que o Aldeamento Santa Isabel poderia ser uma solução ou uma situação menos pior. Pequenos agrupamentos eram formados próximos da Colônia, como o denominado Aldeamento da Lagoa, cerca de $1 \mathrm{~km}$ da sede da Colônia Militar.

O Aldeamento Santa Isabel aglutinava o maior grupo de indígenas, porém, outros se formavam e se extinguiam com a saída da parcialidade ou eram extintos. No caso do de Santa Isabel, "Extinto oficialmente o Aldeamento [1867], os indígenas ficaram entregues à própria sorte, vivendo de caça e do fruto de sua agricultura; com o andar dos anos, os moradores da vizinhança começaram a se queixar às autoridades, reclamando providências; os índios praticavam furtos nas roças, furtavam galinha, porcos e até vacas” (BARBOSA, 1989, p. 15). Atendendo a tais reclamações, o Delegado de Polícia de Lagoa Vermelha [...], à frente de 60 homens armados, fez com que a maior parte dos indígenas se retirassem com suas famílias para a serra do Forquilha, sendo, mais tarde, reunidos no Aldeamento de Faxinal e outros toldos improvisados como o dos campos de José Bueno de Oliveira (BARBOSA, 1989, p. $15)$.

A narrativa do Diretor da Colônia, expressa que “[...], estes se achão sem terras para trabalharem, e as que hião cultivando - tem sido invadidas por particulares, que estão distribuindo as terras nacionaes, a titulo de posse, sem legitimação, expulsando os indios dos terrenos que cultivavão, como se me veio queixar o chefe Bernardino - as extorsões de que são victimas e assim se achão desgostosos - e que não tem mais aonde trabalhar". (Grifo nosso). 


\section{Considerações finais}

A relação da Colônia com os índios foi muita complexa e conflituosa; difícil concluir se o papel da referida em relação aos sujeitos em questão tenha sido cumprido conforme suas intenções. Muitos indígenas não foram aldeados, ficaram sim na região e formaram parcialidades comandadas lideranças por todo o restante do século XIX; descendentes seus hoje reivindicam terras e ampliam os atuais conflitos.

Não há dúvida que o empreendimento colonial, no que tange à questão dos índios, reduziu seus conflitos, algo impossível antes da implantação da Colônia em razão das correrias e outras formas de ataque ${ }^{\mathrm{xxv}}$ como contraposição à intrusão em seus territórios. A Colônia impediu a possibilidade livre e autônoma da circulação indígena pelos seus territórios na medida em que auxiliou a apropriação privada das terras em correspondência com as políticas públicas do momento.

A utilização dos índios nas atividades agrícolas e no extrativismo da erva mate era fundamental para o empreendimento colonizatório da região mediado pela Colônia Militar. Porém, conflitos em torno da questão da erva produzia saída de indígenas do interior do aldeamento situado próximo da Colônia e controlado pela direção dessa. Os ervais do Aldeamento também eram explorados indevidamente por colonos da Colônia Militar e trabalhadores da vizinhança. Os índios aldeados tinham na produção da erva mate uma boa fonte de subsistência econômica. Com isso, a direção da Colônia podia reduzir os soldos dispendidos aos indígenas do Aldeamento Santa Isabel. "[...]. Elles também vivem da caça, o que constitue úm proveito para os mesmos cofres; as plantações, e o fabrico da herva mate na próxima safra, virão igualmente ministrar-lhes úm poderoso meio de subsistência". xxvi

No tocante à produção agrícola pelos indígenas, houve muitos impedimentos. Além das ferramentas escassas, os próprios colonos que se instalaram, muitos deles, não tinham trajetória de produtores rurais; havia muita dificuldade e falta de conhecimento dos ciclos dos produtos produzidos, do combate às pragas, de estratégias de venda dos produtos que não fossem diretamente junto aos comerciantes que passavam pela Colônia. O frio intenso dificultava o completo ciclo de produtos de cultura de verão, como é o caso do feijão, milho, batata, mandioca, dentre outros. A criação de gado era consequência da mesma lógica da 
produção agrícola: ausência de conhecimento, de pastagens, dispersão, sumiço e morte de animais, carência de domínio técnico de domas, potreiros mal feitos e/ou inacabados, doenças e total incapacidade de enfrentá-las sem prejuízos aos animais, entrega de gado para criar em outras fazendas da circunvizinhança, etc.

Os relatórios e os mapas da produção agrícola e animal que revisamos atestam um baixo nível estatístico se levarmos em conta a quantidade de colonos e a extensão da terra da Colônia. Mas isso não foi apenas resultado da pouca presença indígena na atividade e, sim, um somatório de processos. Mesmo depois do fim do aldeamento Santa Isabel, os resultados da produção agrícola não foram melhores. Os indígenas reagiam ao seu modo frente à obrigação de pegar na enxada e em outros instrumentos de trabalho agrícola. Se o faziam e, quando o faziam, era em função de necessidades suas de alimentação e recebimento de soldos ou para barganhar outras questões junto ao seu diretor ou ao diretor da Colônia (proteção frente a inimigos, exploração de pinhais, venda de erva mate, cavalos, roupas, armamentos, evitar o aldeamento forçado em outros espaços, etc.).

Enfim, as duas décadas de existência da referida colônia podem não ter expressado grande volume de produção, mas, sem dúvida, foram fundamentais para a colonização e apropriação privada da terra no centro-norte da província, além de que viabilizaram o extrativismo da erva mate e da madeira, abriram caminhos para passagem de mercadorias agrícolas, tropas de gado e de muares, bem como interligaram territórios e contribuíram, para o controle da esfera pública em relação aos índios existentes na região, promovendo aldeamentos, ainda que sem evitar conflitos entre parcialidades e, também, sem tê-los inserindo como era proposto em atividades produtivas e infraestruturais de interesse público e particular na região.

A produção agrícola em geral e, em particular, na Colônia, era pouco conhecida e desenvolvida até então na região; muitos estancieiros preferiam a criação de gado e a extração de erva mate do que a produção agrícola. Isso foi muito comum em regiões onde houve primeiramente a apropriação de terras por estancieiros em toda a província sulina. Desse modo, a prática agrícola desenvolvida contribuiu, ainda que de uma forma incipiente, para disseminar cultivos, saberes, trocas mercantis, manejo de solos e apropriação privada da terra.

As expectativas iniciais do empreendimento colonizador perpassavam aspectos ligados à proteção e auxílio ao desenvolvimento dos povoados e localidades de seu entorno como um todo, sendo a contenção dos conflitos da população com os indígenas Kaingang crucial e central em seus objetivos. Os caminhos que o Aldeamento de Santa Isabel e a instalação militar tomaram ao longo do crescimento de ambos atestam que, tanto o projeto de 
colonização militar, quanto o dos aldeamentos provinciais, caminharam juntos e partilharam de interesses comuns.

A regulamentação dos requerimentos de títulos de propriedade também perpassou a questão indígena, ao passo que as terras antes devolutas nas quais foi instalada a Colônia, puderam passar a ser concedidas ou comercializadas na região em razão do controle sobre os indígenas, que provera o "esvaziamento" e seguridade dos assentamentos posteriores, dentro e fora dos limites da referida colônia.

\section{Referências}

AVÉ-LALlEMANT, R. Viagens pelas Províncias de Santa Catarina, Paraná e São Paulo (1858). Belo Horizonte: Itatiaia, 1980.

AZEVEDO, F. Jesuítas espanhóis no Sul do Brasil (1842-1867). Pesquisas. História, n. 47. São Leopoldo: Instituto Anchietano de Pesquisas, 1984.

BARBOSA, F. D. Caseiros. Caxias do Sul: Gráfica Universal, 1989, p 12,13,14 e 15.

BECKER, I. O índio kaingang no Rio Grande do Sul. São Leopoldo: Unisinos, 1976 e 1995 (nova edição).

BRANCO, P. de M. Lagoa Vermelha e municípios vizinhos: aspectos naturais, história, genealogia e memórias. Porto Alegre: EST, 1993, p 69.

BRANCO, P. M. A região de Lagoa Vermelha - aspectos históricos. Porto Alegre: EST, 2002, p 71 .

BRINGMANN, S. F. Índios, colonos e fazendeiros: conflitos interculturais e resistência Kaingang nas Terras Altas do Rio Grande do Sul (1829-1860) Dissertação (Mestrado em História). Universidade Federal de Santa Catarina, Florianópolis, 2010.

BRÜGGEMANN, A. A. A sentinela isolada. O cotidiano da Colônia Militar de Santa Thereza (1854-1883). Dissertação em História. PPGH/UFSC, Florianópolis, 2013..

FARIAS, R. H. M. de. Civilizar e desenvolver: duas faces da intervenção militar em áreas internas do Brasil. séculos XIX e XX. Revista de Pesquisa Histórica, n. 29, 2011.

FRANCISCO, A. R. Kaingang: uma história das interações entre nativos e ocidentais durante a conquista e a colonização no sul do Planalto Meridional. Tese (Doutorado em História). PUC-RS. Porto Alegre. 2013.

GOLIN, T. Território Kaingang - Passo Fundo e Mato Castelhano. Documentação sobre a presença histórica Kaingang em Mato Castelhano. Núcleo de Documentação Histórica. Passo Fundo: UPF, 2007.

HOLANDA, M. A. F. et al. Relatório circunstanciado de identificação da Terra Indígena Fág Ty Ka-Mato Castelhano/RS. Brasília: Funai, 2012.

KUJAWA, H.; BADALLOTI, R. Relatório de perícia fundiária: Mato Castelhano. Chapecó, agosto de 2016. 
LAROQUE, L. F. Fronteiras geográficas, étnicas e culturais envolvendo os Kaingang e suas lideranças no Sul do Brasil (1889-1930). Antropologia, n. 64, Pesquisas/Instituto Anchietano, 2007.

LAROQUE, L. F. Lideranças Kaingang no Brasil Meridional (1808-1889). Antropologia, n. 56, Pesquisas/Instituto Anchietano, 2000.

MABILDE, P. F. A. B. Apontamentos sobre os indígenas selvagens da Nação Coroados dos matos da Província do Rio Grande do Sul - 1836-1866. São Paulo: IBRASA/Prómemória/INL, 1983 p 165.

MAGALHÃES, J. C. Memória sobre as colônias militares, nacionais e indígenas. Rio de Janeiro: Tipografia da Reforma, 1875.

MYSKIW, A. M. A fronteira como destino de viagem: a colônia militar de Foz do Iguaçu (1888/1907). Tese (doutorado). Universidade Federal Fluminense: Niterói/RJ. 2009.

PEZAT, P. R. Auguste Comte e os fetichistas: estudo sobre as relações entre a Igreja Positivista do Brasil, o Partido Republicano Rio-Grandense e a política indigenista na República Velha. 1997. Dissertação (Mestrado em História) - Programa de Pós-Graduação em História, Universidade Federal do Rio Grande do Sul, Porto Alegre, p 270.

ROCHA, C. Adoecer e curar. Processos de sociabilidade Kaingang. Dissertação em Antropologia Social. UFSC, Florianópolis, 2005, p 86.

SIMONIAM, L. Identificação e delimitação da Terra Indígena Monte Caseros, localizada nos municípios de Muliterno e Ibiraiaras - RS. Brasília: Funai, Agosto de 1995.

SODRÉ, N. W. História militar do Brasil. 2. ed. São Paulo: Expressão Popular, 2010.

STANGERLIN, N. M. L. Cacique Doble: caminhada histórica. Porto Alegre: Posenato Arte e Cultura, 1989.

VIANNA, Marcelo. A Colônia Militar Caseros: experiência de fracasso no sucesso da expansão territoria1 sul-rio-grandense. In: BEMFICA, Corália. (Org.). Raízes de Santo Antônio da Patrulha e Caraá. Porto Alegre: EST, 2000b, p. 161- 173.

XAVIER, M. O Coronel Freitas e a Colônia Militar do Chapecó - os primórdios de Xanxerê e a colonização do Oeste Catarinense. Florianópolis: Editora Insular, 2016.

Recebido: $21 / 10 / 2018$

Aceito: $18 / 01 / 2019$

Publicado: 13/05/2019

\footnotetext{
${ }^{i}$ Doutor em Ciências Sociais pela Universidade Estadual de Campinas (1998), especialista em economia. Fez estágio de pós-doutoramento (2002) e de professor visitante (2009, 2014 e 2018) na Universidade de Verona - Itália. Fez também segundo pós-doutoramento (2011) na Universidade de Milão (Itália). Professor titular da Universidade de Passo Fundo no Mestrado e Doutorado em História. E-mail: jctedesco@upf.br

ii Relatório de João de Almeida Pereira Filho, Ministro do Império, em 1859, apud XAVIER, M. O Coronel Freitas e a Colônia Militar do Chapecó - os primórdios de Xanxerê e a colonização do Oeste Catarinense. Florianópolis: Editora Insular, 2016, p. 33.

iii Há vários casos de colônias militares no norte do país que foram extintas em razão de surtos de malária e de outras doenças. Em outros espaços, principalmente do sul do país, grupos indígenas localizados próximos às colônias militares, foram acometidos por doenças que dizimaram quase todo o coletivo. Na Colônia Militar de Caseros, essa questão se apresentou com grande intensidade.
} 


\begin{abstract}
iv Relatório apresentado à Assembleia Geral Legislativa na segunda sessão da décima legislatura pelo ministro e secretário de Estado dos Negócios da Guerra Jeronymo Francisco Coelho. Rio de Janeiro: Typografia Universal de Laemmert, 1868, p. 15.

${ }^{v}$ Relatório do Vice-presidente da Província de S. Pedro do Rio Grande do Sul, Oliveira Bello, apresentado à Assembleia Legislativa Provincial. Porto Alegre: Typographia do Correio do Sul, 01-10-1852, p. 17.

vi Ver TEDESCO, J. C.; VANIN, A. Entre a espada, a cruz e a enxada: a Colônia Militar de Caseros no norte do Rio Grande do Sul (1858-1878). Erechim: All Print, 2018, 391 pag.

vii BRASIL. Ministério do Império. Relatório do ano de 1857, apresentado à Assembleia Geral Legislativa na $2^{\mathrm{a}}$ Sessão da $10^{\mathrm{a}}$ Legislatura. Ministro e Secretário de Estado dos Negócios do Império Marquês de Olinda. Rio de Janeiro: Typographia Universal de Laemmert, 1858, p. 37, apud BRÜGGEMANN, A. A. A sentinela isolada..., op., cit., p. 66.
\end{abstract}

viii Aldeamento Santa Izabel, 29 de janeiro de 1859. AHRS, apud Holanda et al. (2012).

ix Acampamento no Passo do Jacuhy, 22 de outubro de 1842. AHRS - Coleção Varela, vol. 16, apud, Holanda et al. (2012, p. 51). Grifo nosso.

× José Lopes de Oliveira e Hortencio Maria da Gama Souza Mello.

xi Relatório enviado pelo diretor da Colônia Militar de Caseros, Hortencio M. da Gama Souza Mello, à Presidência da Província. Colônia Militar de Caseros, em 31/07/1861. AHRS. Fundo Colonização. Maço 48.

xii Relatório enviado pelo diretor da Colônia Militar de Caseros, Hortencio M. da Gama Souza Mello, à Presidência da Província. Colônia Militar de Caseros, em 18/08/1862. AHRS. Fundo Colonização. Maço 48.

xiii Ofício do Padre Antonio de Moraes Branco ao Presidente da Província Francisco Assis Pereira Rocha. Colônia Militar de Caseros, em 31/10/1862b. AHRS. Arquivo Índios.

xiv Ofício do Padre Antonio de Moraes Branco ao Presidente da Província Francisco Ignacio Marcondes Homem de Mello. Colônia Militar de Caseros, em 04/05/1867. AHRS. Arquivo Índios.

xv Correspondência Expedida pelo Presidente da Província ao Ministério da Guerra, em 13/03/1861. AHRS Fundo Correspondências Expedidas.

xvi Correspondência do Diretor do Aldeamento de Santa Isabel ao Presidente da Província, em 10/07/1858. AHRS - Fundo Indígenas - Santa Isabel - lata 299, maço 02.

xvii Relatório do Presidente da Província de S. Pedro do Rio Grande do Sul Angelo Moniz da Silva Ferraz apresentado à Assembleia Legislativa Provincial. Porto Alegre: Typographia do Correio do Sul, 05-11-1858, p. 29. Grifo nosso.

xviii Relatório do Presidente da Província de S. Pedro do Rio Grande do Sul Angelo Muniz da Silva Ferraz apresentado à Assembleia Legislativa Provincial. Porto Alegre: Typographia do Correio do Sul, em 22/04/1859, p. 17.

xix Ofício do Padre Antonio de Moraes Branco ao Presidente da Província Francisco Assis Pereira Rocha. Colônia Militar de Caseros, em 31/10/1862a. AHRS. Arquivo Índios.

xx Idem.

xxi Correspondência do Diretor da Colônia Militar de Caseros ao Presidente da Província, em 04/03/1862. AHRS - Fundo Colonização - Caseros - lata 292, maço 48.

xxii Ofício do Diretor do Aldeamento de Santa Izabel, Alberto Marques de Almeida, ao Presidente da Província Joaquim Fernandes Leão. Aldeamento de Santa Izabel, em 16/11/1859. AHRS. Arquivo Índios.

xxiii Correspondência do Diretor do Aldeamento de Santa Isabel ao Presidente da Província, em 13/11/1862. AHRS - Fundo Indígenas - Santa Isabel - lata 299 maço 02.

xxiv Ofício do Padre Antonio de Moraes Branco ao Presidente da Província Francisco Assis Pereira Rocha. Colônia Militar de Caseros, em 31/10/1862a. AHRS. Arquivo Índios.

${ }^{x \times v}$ Isso é muito evidenciado pela ampla literatura existente que aborda o povoamento da região de Passo Fundo, inclusive com episódios envolvendo parcialidades indígenas ocorridos durante a Revolução Farroupilha pela passagem de tropas, de ambas as partes envolvidas, nos matos Castelhano e Português.

xxvi Ofício de Antônio de Moraes Branco, Diretor do Aldeamento de Santa Izabel ao Presidente da Província, Joaquim Fernandes Leão. Aldeamento de Santa Izabel, em 20/08/1862. AHRS. Arquivo Índios. 